Matematikai Közlemények

VII. kötet, 2019

doi:10.20312/dim.2019.02

\title{
Közelítő szögharmadolás szerkesztése GeoGebrával
}

\author{
Talata István \\ Szent István Egyetem, \\ Ybl Miklós Építéstudományi Kar, Budapest, \\ és Dunaújvárosi Egyetem, Dunaújváros \\ talata.istvan@ybl.szie.hu
}

\begin{abstract}
ÖSSZEFOGLALÓ. Ismert, hogy körzővel és vonalzóval nem szerkeszthető meg egy tetszőleges szög harmada, de a szögharmadhoz tetszőleges pontossággal lehet közelítő szöget szerkeszteni. Azt vizsgáljuk, hogy melyik szerkesztési eljárással érdemes sok tizedesjegynyi pontosságú közelítő szögharmadolási szerkesztést elvégezni úgy, hogy viszonylag kevés szerkesztési lépésre legyen ehhez szükségünk. Azzal is foglalkozunk, hogy mennyivel növekszik a szükséges szerkesztés lépések száma a vizsgált közelítő szögharmadolási módszerek alkalmazása során, a pontosság növelésével. A szerkesztések GeoGebrával történő elkészíthetőségét, valamint annak szoftveres korlátait is elemezzük, és vizsgáljuk, hogyan módosíthatunk a szerkesztési lépéseken a szoftveres ábrázolhatóság érdekében.
\end{abstract}

\begin{abstract}
It is known that an arbitrary angle can not be trisected by a Euclidean construction (a construction using compass and ruler only). However, an approximate angle trisection can be constructed this way, within any given level of precision. We consider the problem that which approximate angle trisecton method produces good accuracy for many digits in a way that relatively few construction steps are needed to achieve that in a Euclidean construction. We also investigate by how much the number of construction steps is increasing during performing the different construction methods as the accuracy of the approximation is increasing. We analyze the realizability of the constructions with GeoGebra with espect to the software limitations, and we consider how to modify some construction steps, so the constructions become representable with GeoGebra.
\end{abstract}

\section{Bevezetés}

A szögharmadolás egyike a híres ókori görög matematikai feladatoknak (a másik két ilyen feladat a kör négyszögesítése és a kockakettőzés). Mindhárom geometriai szerkesztési feladat, melyekről kiderült, hogy nem oldhatók meg körzővel és vonalzóval történő szerkesztésekkel.

A szögharmadolási feladat - azaz, hogy adott $\alpha$ szög esetén körzővel és vonalzóval szerkesszünk meg egy harmadakkora szöget - lehetetlennek bizonyult általános esetben, sőt minden olyan konkrét esetben is, amikor a $p(x)=4 x^{3}-3 x-\cos (\alpha)$ polinom irreducibilis a $\mathbb{Q}(\cos (\alpha))$ testbővítés felett (azaz nem bontható fel kisebb fokszámú tényezők szorzatára úgy, hogy a tényezők olyan polinomok legyenek, melyek együtthatói a $\mathbb{Q}(\cos (\alpha))$ test elemei), ld. [9]. Ez a helyzet például, ha a harmadolandó $\alpha$ szög koszinusza racionális szám, és $p(x)$ a racionális számok felett irreducibilis polinom. Ezért a $60^{\circ}$-os szög nem harmadolható, mert $\cos \left(60^{\circ}\right)=\frac{1}{2}$, és $4 x^{3}-3 x-\frac{1}{2}$ irreducibilis polinom a racionális számok felett.

KULCSSZAVAK. Szögharmadolás, euklideszi szerkesztés, Taylor-sor.

KEYWORDS. Angle trisection, Euclidean construction, Taylor series. 
Amiatt, hogy egy tetszőleges szög egész számú többszöröse megszerkeszthető körzővel és vonalzóval, nem csak $20^{\circ}$-os szög nem szerkeszthetö, hanem $10^{\circ}$-os, $5^{\circ}$-os és $1^{\circ}$-os szög sem, valamint mivel tetszőleges szög felezhető körzővel és vonalzóval, ezért $40^{\circ}$-os és $80^{\circ}$-os szög sem szerkeszthető. A szögharmadolási feladat megoldhatatlanságát már az ókor óta sejtették, de bebizonyítani csak a 19. században tudták (Wantzel, 1837).

Bizonyos módokon mégis lehetséges a szögharmadolás, és így feloldhatjuk a megoldhatatlanságot: ha más megfelelö segédeszközt (pl. megjelölhető élü vonalzót), vagy körzővel és vonalzóval nem szerkeszthetö segédgörbét (pl. triszektrix) is használunk a szerkesztéshez, esetleg ha nem pontos szögharmadolást szeretnénk megszerkeszteni, hanem annak csupán egy közelítését, adott hibahatáron belül, ld. [1].

Ebben a tanulmányban közelítő szögharmadolással fogunk foglalkozni: olyan szerkesztésekkel, amelyekkel sok tizedesjegynyi pontossággal közelíthetjük meg egy tetszölegesen adott szög harmadát körzővel és vonalzóval elvégezhető szerkesztési lépések sorozatának eredményeként, hogy például számítógépes geometriai szoftverrel, a szoftver által alkalmazott numerikus módszerek hibahatárán belül megszerkeszthessük a szögharmadot. Valamint foglalkozni fogunk a szerkesztés szoftveres ábrázolásának a nehézségeivel is, és hogy hogyan módosíthatjuk a szerkesztést úgy, hogy a szerkesztés összes lépését megjeleníthessük. A GeoGebra szoftver (ld. [6]) használatának példáján keresztül mutatjuk mindezt be.

\section{Közelítő szögharmadolás}

Szerkesztésen ebben a cikkben mindig körzővel és vonalzóval történő szerkesztést értünk, az ilyet euklideszi szerkesztésnek is szokták hívni.

Egy tetszöleges $\alpha$ szög harmadának egy adott $\varepsilon>0$ hibahatáron belüli közelítését megszerkeszthetjük a következőképp: mivel egy szögfelezés elvégezhető körző és vonalzó segítégével, és az eredményül kapott szögre ezt egymás után többször alkalmazva tetszöleges kis szög szerkeszthető, ezért ha az $\varepsilon$ hibahatárnál kisebb $\delta$ szöget szerkesztünk megfelelően sokszori egymás utáni szögfelezéssel, akkor a $\delta$ szögnek megfelelő sokszori többszörözésével tetszőleges szögnek, így pl. az $\alpha$ szög harmadának egy közelítését is megkaphatjuk $\varepsilon$ hibahatáron belül. Például a $k \delta$ egy ilyen közelítő szögharmadolás (ahol $k$ egy pozitív egész szám), ha $(k-1) \delta<\frac{\alpha}{3} \leq k \delta$ igaz, és ez ekvivalens a $3(k-1) \delta<\alpha \leq 3 k \delta$ egyenlötlenség teljesülésével, azaz azt kell csak figyelni a $3 \delta$ szög többszöröseinek a szerkesztésekor, hogy melyik lépésben lesz a nagysága legalább $\alpha$.

A jelenleg elterjedt számítógépes szoftverek, ill. geometriai szerkesztő szoftverek közül több is nagy pontosságú számításokat tesz lehetővé sok tizedesjegynyi értékig kiszámítva pontok koordinátáit, távolságokat, szögek nagyságát és sok más mennyiséget, és a számításokhoz tartozó ábrákon, ill. a szerkesztések ábráin mindezt ábrázolhatjuk is, a felhasználó által testreszabott módon. Például a GeoGebra 15 tizedesjegynyi pontossággal is megjelenítheti a mennyiségeket.

Ez összhangban van azzal, hogy a számítógépes szoftverek numerikus számításaiban jelenleg a legelterjedtebb az IEEE 754-es szabványban leírt dupla pontosságú bináris lebegőpontos számformátum használata, amely egy kettes számrendszeren alapuló 64 bites számformátum: 52 bit a mantissza, 1 bit az előjel, 11 bit a karakterisztika tárolására szolgál egy 64 bites adatmennyiségben, ld. [7], [8]. Ezért egy szám lebegöpontos ábrázolása ebben a rendszerben a $\pm(1+m) 2^{k}$ alakban történik, ahol $m$ egy legfeljebb 52 számjegyü bináris tört, $0 \leq m<1,-1022 \leq k \leq 1023$ (1-1 érték fenn van tartva a gépi végtelen (Inf, ,infinity”) és a számot nem eredményező ( $N a N$, „not a number”) gépi számítások számára, ezért nem $2^{11}=$ 2048 különböző értéket vehet fel $k$, hanem csak 2046-ot). Ezért a legkisebb pozítív $m$ értéke 
(amit gépi epszilonnak is szoktak hívni) $2^{-52} \approx 2.2 \times 10^{-16}$ ez 15 tizedesjegynyi pontosságú számábrázolást jelent. Ebben a számformátumban a legkisebb pozitív szám $2^{-1022} \approx 10^{-308}$ nagyságrendü, a legnagyobb szám pedig $2 \times 2^{1023} \approx 10^{308}$ nagyságrendü, ha a számoknak a felhasználók számára történő tízes számrendszerbeli $c \times 10^{n}$ exponenciális alakú megjelenítési lehetőségét is figyelembe vesszük.

Megjegyezzük, hogy bizonyos szoftverek esetén lehetőség van szimbolikus számításokra is, és a geometriai eredményeket így is tárolhatjuk egy bizonyos bonyolultságig. Pl. a GeoGebra Komputeralgebra (CAS) nézetében elvégzett több müvelet esetén is ez a helyzet, de mivel a szerkesztési lépések elörehaladtával a számítások egyre bonyolultabb képleteket eredményeznek, eljön a pont, amikor a GeoGebra átvált közelítő törtekkel való számításra, mert képleteknek nagyon sokszori egymásba ágyazása már nincs benne támogatva, hogy a szoftver futása ne lassuljon le.

Ha a körzővel és vonalzóval történő szerkesztésekhez geometriai szoftvereket használunk, akkor a szoftvertől függően, de általában sok tizedesjegynyi pontossággal ellenőrizhetjük a megszerkesztett távolságokat, körsugarakat, szögek nagyságát. És ebben az esetben közelítő szerkesztéseket végrehajtva, a szerkesztési pontosság ellenőrzésére és nagy pontosság elérésére is van lehetöség.

Ezért felmerülnek a következő kérdések:

1. Probléma. Hogyan lehet közelítő szögharmadolást nagy pontossággal, viszonylag kevés szerkesztési lépéssel elkészíteni? Melyik szerkesztési módszert érdemes használni?

2. Probléma. Hogyan viszonyul egymáshoz a közelítő szögharmadolás szerkesztési pontosságának a növelése, valamint az adott pontosság eléréséhez szükséges szerkesztési lépések számának a növekedése?

Ezekre a problémákra keressük a választ a későbbiekben, csak előbb tisztázzuk, hogy pontosan mit is értünk szerkesztési lépéseken.

\section{Szerkesztési lépések}

Az euklideszi szerkesztések esetén az eredetileg használható idealizált szerkesztési segédeszközök: az egyélü vonalzó, és az összecsukódó körző. Tehát a vonalzónak csak az egyik éle használható szerkesztésre (így például nem szerkeszthető párhuzamos egyenespár a vonalzó két különböző élének berajzolásával). A vonalzó nem megjelölhető, tehát például pontok vagy távolságok megjelölése nem lehetséges rajta. A körzővel pedig olyan kör szerkeszthető, amelynek középpontja és egy kerületi pontja adott, mivel felemeléskor összecsukódik, így távolság körzőnyílásba vételére és átvitelére nem alkalmas.

Persze a modern körző már nem összecsukódó, és manapság szerkesztésekkor az egyélü vonalzó használata mellett gyakran derékszögü vonalzót is használnak, de mindezzel nem bővül a szerkeszthető elemek köre: már Euklidész megmutatta az Elemek c.müvében, hogy távolságok átvitele lehetséges az összecsukódó körző segítségével (ebből következik, hogy a modern körző szerkesztései megvalósíthatók az összecsukódó körzővel is), valamint hogy párhuzamos és merőleges egyenesek szerkeszthetők körzővel és vonalzóval is - így a derékszögü vonalzó használata csak egyszerüsíti az ilyen szerkesztéseket.

Szerkesztési lépéseken a szerkesztések legkisebb alapegységeit értjük, ezeket szerkesztési alaplépéseknek, vagy elemi szerkesztési lépéseknek is szokás nevezni, de ebben a cikkben többnyire csak egyszerüen szerkesztési lépéseknek hívjuk őket. A klasszikus szerkesztési lépések a következők: 
1) Két, már megszerkesztett ponton keresztül vonalzóval egyenest húzhatunk.

2) Két, már megszerkesztett pont esetén szerkeszthetünk olyan kört, melynek az egyik pont a középpontja, a másik pont pedig egy kerületi pontja.

3) Két, már megszerkesztett metsző egyenes metszéspontja megszerkeszthető.

4) Már megszerkesztett, egymást metsző kör és egyenes bármelyik metszéspontja megszerkeszthetö.

5) Már megszerkesztett, egymást metsző két kör bármelyik metszéspontja megszerkeszthetö.

Vegyük észre, hogy a 4)-5) szerkesztési lépésekben az alakzatok (egyenes és kör, két kör) nem lehetnek érintők. Ezen felül, a modern körzö és a derékszögü vonalzó (egyélü vonalzóval kombinált) használatával, szerkesztési alaplépéseknek tekinthetők a következők is:

6) Három, már megszerkesztett pont esetén szerkeszthető olyan kör, amelynek a középpontja az első pont, a sugara pedig megegyezik a második és harmadik pont távolságával (azaz körzőnyílásba vehető két pont távolsága).

7) Már megszerkesztett pont és rá nem illeszkedő, megszerkesztett egyenes esetén szerkeszthető a ponton átmenő és az adott egyenessel párhuzamos egyenes.

8) Már megszerkesztett pont és egyenes esetén szerkeszthető a ponton átmenő és az adott egyenesre meröleges egyenes.

Megjegyezzük, hogy sokan külön alaplépéseknek tekintik a körzőnyílásba vételt és az adott középponttal és körzőnyílással rendelkező kör szerkesztését.

Mesterségesnek tünhet az idealizált szerkesztési segédeszközöknek a használata, és minden szerkesztésnek az ezekhez kapcsolódó szerkesztési szabályokra történő visszavezetése, de ez biztosítja, hogy elméleti vizsgálatokra van lehetőség a szerkeszthetőséget és a szerkesztések bonyolultságát (ld. lépésszámát) illetően.

A modern körzőhöz és a derékszögü vonalzó használatához kapcsolható, utolsó három szerkesztési lépés mindegyikét kiválthatjuk konstans (nem is túl sok) lépésből áll olyan szerkesztéssel, amely csupán a klasszikus szerkesztési lépéseket tartalmazza.

A geometriai szoftverek a gyakrabban használt szerkesztési feladatok megoldásait beemelhetik a szerkesztési eszközök közé, mint pl. a szakaszfelező pont, szakaszfelező meröleges, szögfelező egyenes, három ponton áthaladó kör, körhöz húzott érintő egyenes szerkesztése esetén. De a számítógépes szerkesztési eszközök nem csak körzővel és vonalzóval megvalósítható szerkesztéseket emgedhetnek meg, pl. bármilyen beírt értékű szöggel történő forgatás is lehetséges GeoGebrában. Ezért célszerü csak a fentebbi nyolc (ill., ha a derékszögü vonalzó használatát nem engedjük meg, akkorhat) szerkesztési lépést elemi lépésnek tekinteni (a modern körzőt használják mindenhol, így a 6)-os számú szerkesztési lépést szerkesztési alaplépésnek tekintjük - 1 vagy 2 lépésnek), és csakis az ezeknek megfelelő eszközöket használni geometriai szoftverek futtatásakor, amikor körzővel és vonalzóval elvégezhető szerkesztéseket szeretnénk készíteni, hiszen minden euklideszi szerkesztés visszavezethető ezekre, és ilyenkor a szerkesztési lépések száma jól jellemzi a szerkesztésünk bonyolultságát.

Minden szerkesztés elején legalább két pont kell, hogy legyen adva (vagy annyi más egyenes, ill. kör, hogy azok metszéspontjaival együtt legyen legalább két pont), és két pont távolságára feltehető, hogy egységnyi (mert hasonlóság erejéig ekvivalens egy ilyen szerkesztés bármely másikkal). A harmadolandó szög lehet olyan, amely megszerkeszthető két adott pontból szerkesztési lépések egymás utáni alkalmazásával (pl. ilyen a $60^{\circ}$-os szög), vagy lehet ettől eltérő típusú, mondjuk három adott pont által meghatározott szög, ahol a harmadik pont nem szerkeszthető meg az első kettőböl euklideszi szerkesztéssel. 


\section{Szerkesztési módszerek}

Elöször három szerkesztési eljárást ismertetünk, amelyekkel közelítő szögharmadolást valósíthatunk meg. Egy $60^{\circ}$-os szög esetén ezekkel a szögharmadolás közelítése $1^{\circ}$-os hibahatáron belül történik. Mindegyik esetben feltehetjük, hogy adott a szög $A$ csúcsa, és a szögszáraknak az A csúcs körüli egységnyi sugarú $c$ körrel vett $B$ és $C$ metszéspontjai: $\alpha=$ $B A C \angle$.

1. eljárás (húrharmadolás): $A B C$ húrt harmadoljuk a párhuzamos szelők tételét alkalmazva, és az egyik távolabbi (azaz nem a középső) húrharmadot kimetsző középponti szöget $(\beta=B A F \angle)$ vesszük. Ez talán a legegyszerübb, legrövidebb közelítő szögharmadolási szerkesztés, nem túl pontos, de nem is túl pontatlan (ld. 1. ábra).

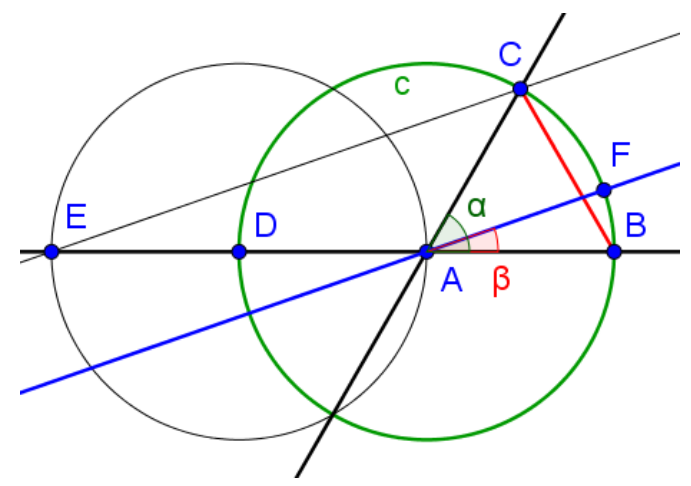

1. ábra. A $B A F \angle$ szerkesztése húrharmadolással

2. eljárás (Steinhaus módszere): Az $\alpha$ szöget felezzük az $A D$ egyenessel, majd a $B E$ húrt harmadoljuk a $H$ pontban a párhuzamos szelők tételét alkalmazva, és a $B H$ húrdarabot kimetsző középponti szöget ( $\beta=B A I \angle)$ vesszük (ld. 2. ábra, és [2], [5]).

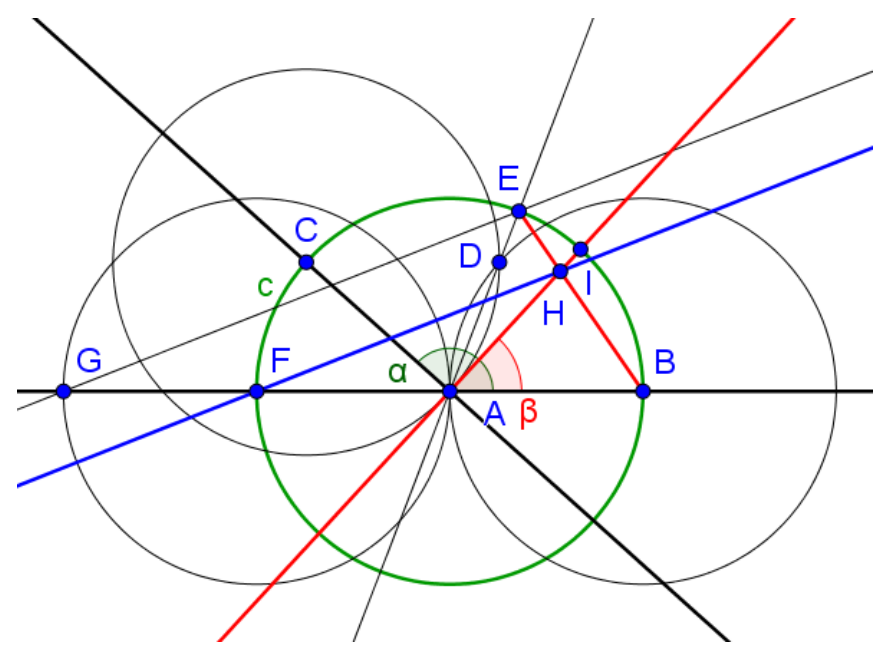

2. ábra. A BAI $\angle$ szerkesztése szögfelezés utáni húrharmadolással

3. eljárás (Segar módszere): A $c$ körben a $B, C$ pontokkal átellenes pontok legyenek $B^{\prime}$, ill. $C^{\prime}$. Az $\alpha$ szög szögfelezője (amely párhuzamos a $B^{\prime} C$ egyenessel) a $c$ kört a $D$ pontban metszi. A $D A C \angle$ szögfelezője (amely párhuzamos a $D^{\prime} C$ egyenessel, ahol $D^{\prime}$ a $D$-vel szemközti pontja a $c$ körnek) a $c$ kört az $E$ pontban metszi. A $D^{\prime} E$ és $C^{\prime} D$ egyenesek metszéspontja legyen I. Ekkor $\beta=I A C \angle$ adja a közelítő szögharmadolást (ld. 3. ábra és [5]). 


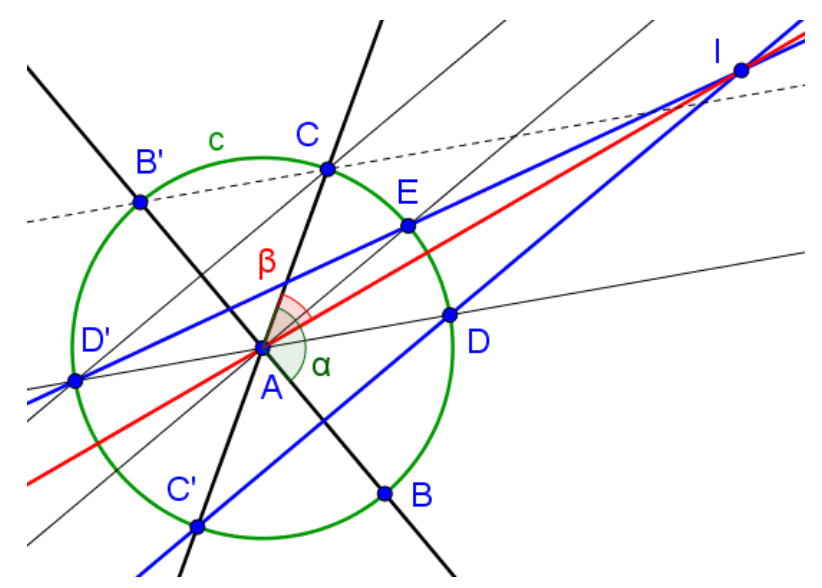

3. ábra. A $I A C \angle$ szerkesztése szelők I metszéspontja alapján

Ha $\alpha$ egy $60^{\circ}$-os szög, akkor annak közelítő harmadolására az 1. esetben $\beta=$ $19.1066 \ldots{ }^{\circ}$, a 2 . esetben $\beta=20.1039 \ldots{ }^{\circ}$, a 3 . esetben pedig $\beta=19.9872 \ldots{ }^{\circ}$ szögnagyságok jönnek ki.

Az 1. eljárásban végül is egy szakasznak (amely egy egyenlő szárú háromszög alapja) a harmadolásából jön ki a közelítő szögharmadolás - ez a szögharmadolási problémát annak megoldhatatlansága ellenére megoldani kívánó „szögharmadolók” egyik kedvenc módszere (persze az ügyesebbek az eredetinél egy jóval kisebb szög harmadolására alkalmazzák, míg az adott szögnek a másik, nagyobbik részét egy pontosan megszerkeszthető szög háromszorosaként állítják elö, hogy ne legyen olyan feltünő az ügyeskedésük, és nagyobb pontosságú legyen a közelítő szögharmadolásuk), csak ők ezzel a szögharmadolást pontosan szeretnék megoldani, mi pedig elfogadjuk, hogy ez csupán egy közelítő szögharmadolást eredményez.

Tetszőleges pontosságú közelítő szögharmadolást szerkeszthetünk bármely konkrét közelítő szögharmadolási eljárás egymás után többszöri alkalmazásával, ha az eljárás a szögharmadnak legalább a felét közelíti tetszőleges szögre: az eljárás valahanyadik alkalmazása után eredményül kapott $\beta$ közelítő szögharmadból kiszámolt $\alpha-3 \beta$ eltérés szögének az abszolút értékére újra alkalmazzuk az eljárást, végül az eredményül kapott közelítő szögharmadok \pm 1 -szereseinek összege adja majd ki a pontosabb közelítő szögharmadolását az eredeti $\alpha$ szögnek, megfelelően választott + , ill. - elöjelekkel.

Precízebben: legyen $f:[0, \pi) \rightarrow[0, \pi), x \mapsto f(x)$ az a függvény, amely megadja, hogy egy tetszőleges $x$ szög esetén $f(x)$ lesz a szögharmad közelítése a konkrét szögharmadolási szerkesztési eljárás eredményeként, és legyen $n$ egy pozitív egész szám. Definiáljuk a következőket: $\alpha_{0}=\alpha, \beta_{i}=f\left(\alpha_{i-1}\right), \alpha_{i}=\left|\alpha_{i-1}-3 \beta_{i}\right|, \delta_{i}=\operatorname{sgn}\left(\alpha_{i-1}-3 \beta_{i}\right)$, amikor $1 \leq i \leq n$. (Tehát $\delta_{i}$ értéke +1 ill. -1 az $\alpha_{i-1}-3 \beta_{i}$ eltérés előjele szerint.) Ezzel rekurzívan definiáltuk az $\alpha_{0}, \alpha_{1}, \ldots \alpha_{n}$ szögsorozatot, valamint a $\beta_{1}, \beta_{2}, \ldots, \beta_{n}$ közelítő szögharmadolások sorozatát és a $\delta_{1}, \delta_{2}, \ldots \delta_{n}$ elöjelsorozatot (amely az $\alpha_{i-1}-3 \beta_{i}$ eltérések elöjeleit kódolja).

Ekkor

$$
\begin{aligned}
& \alpha=3 \beta_{1}+\delta_{1} \alpha_{1}=3 \beta_{1}+\delta_{1}\left(3 \beta_{2}+\delta_{2} \alpha_{2}\right)=\cdots \\
& \ldots=3 \beta_{1}+\sum_{k=2}^{n}\left(\left(\prod_{i=1}^{k-1} \delta_{i}\right) 3 \beta_{k}\right)+\left(\prod_{i=1}^{n} \delta_{i}\right) \alpha_{n},
\end{aligned}
$$

azaz az $\alpha$ szögre adódó nagyobb pontosságú közelítő szögharmadolás a

$$
\beta=\beta_{1}+\gamma_{1} \beta_{2}+\cdots+\gamma_{n-1} \beta_{n}
$$


szögként szerkeszthetö meg, ahol $\gamma_{i}=\delta_{1} \delta_{2} \ldots \delta_{i}, 1 \leq i \leq n-1$ (tehát $\gamma_{i} \in\{-1,+1\}$ ).

Fennáll $\frac{1}{3}=\frac{1}{2}-\frac{1}{4}+\frac{1}{8}-\cdots+\frac{1}{2^{2 k}}-\frac{1}{2^{2 k+1}}+\cdots$, és $\frac{1}{3}=\frac{1}{4}+\frac{1}{16}+\cdots+\frac{1}{4^{n}}+\cdots$ a végtelen mértani sorozatok összegképlete alapján, ezért az $\alpha$ szög harmada felírható kétféleképp, egy $n$ tagú mértani sorozat elemeinek az összegéhez hozzáadva a maradéktagot (ld. [1]):

$$
\frac{\alpha}{3}=\left(\frac{\alpha}{2}-\frac{\alpha}{4}+\frac{\alpha}{8}-\cdots+(-1)^{n-2} \cdot \frac{\alpha}{2^{n-1}}+(-1)^{n-1} \cdot \frac{\alpha}{2^{n}}\right)+(-1)^{n} \frac{\alpha}{3} \cdot \frac{1}{2^{n}},
$$

és

$$
\frac{\alpha}{3}=\left(\frac{\alpha}{4}+\frac{\alpha}{16}+\cdots+\frac{\alpha}{4^{n}}\right)+\frac{\alpha}{3} \cdot \frac{1}{4^{n}} .
$$

Mindkét összegképlet alapján elmondható, hogy szögfelezésekkel megszerkeszthető az egyes képletekben szereplő $n$ tagú mértani sorozat összege, az elsőnél tagonként felére csökken az eltérés, a másodiknál pedig tagonként negyedére csökken az eltérés $\frac{\alpha}{3}$-tól (de ott tagonként két szögfelezés egymásutánja szükséges a szögnegyedeléshez). Mivel egy szögfelezés legalább 4 szerkesztési lépést igényel, és $\alpha \geq 1$ esetén legalább 50 szögfelezés szükséges ahhoz, hogy 15 tizedesjegyre (azaz 52 bináris jegyre) megközelítse a szerkesztett szögösszeg az $\frac{\alpha}{3}$ szöget, így legalább $50 \cdot 4=200$ szerkesztési lépésre van ehhez szükség csak szögfelezések, és esetleges szögösszegek, ill. különbségek szerkesztésével.

Felírva a fejezet elején leírt 1-3. közelítő szögharmadolási eljárások szögharmadot közelítő eredményeinek függvényképleteit, és az azokhoz tartozó Maclaurin-sor (azaz a 0 helyen vett Taylor-sor) első néhány tagját (ld. [4]), a következők adódnak (a Maclaurin-polinomok esetében radiánban vett $\alpha$ szögértékekkel számolva, radiánban jön ki az eredmény; a trigonometrikus függvényeket tartalmazó képletek fokban vett szögértékek esetén helyes eredményt adnak fokokban számolva is):

Az 1. eljárás függvénye: $\quad f_{1}(\alpha)=\frac{\alpha}{2}-\operatorname{arctg}\left(\frac{\operatorname{tg}\left(\frac{\alpha}{2}\right)}{3}\right)=\frac{\alpha}{3}-0.0123 \ldots \cdot \alpha^{3}+O\left(\alpha^{5}\right)$

A 2. eljárás függvénye:

$$
f_{2}(\alpha)=\operatorname{arctg}\left(\frac{2 \sin \left(\frac{\alpha}{2}\right)}{1+2 \cos \left(\frac{\alpha}{2}\right)}\right)=\frac{\alpha}{3}+0.0015 \ldots \cdot \alpha^{3}+O\left(\alpha^{5}\right)
$$

A 3. eljárás függvénye:

$$
f_{3}(\alpha)=\operatorname{arctg}\left(\frac{\sin \left(\frac{\alpha}{2}\right)+2 \sin \left(\frac{\alpha}{4}\right)}{\cos \left(\frac{\alpha}{2}\right)+2 \cos \left(\frac{\alpha}{4}\right)}\right)=\frac{\alpha}{3}-0.00019 \ldots \cdot \alpha^{3}+O\left(\alpha^{5}\right)
$$

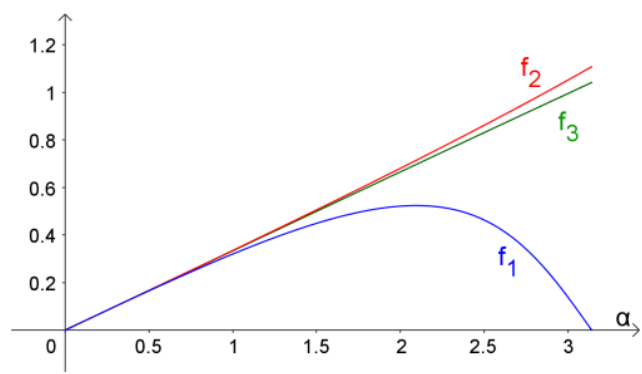

4. ábra. A vizsgált három közelítő szögharmadolási eljárás kimeneti függvényei

Tehát $f_{i}(\alpha)$ egy harmadrendü közelítése $\frac{\alpha}{3}$-nak $(i=1,2,3)$, azaz a különbségük egy konstans $\cdot \alpha^{3}$ típusú képlettel felülről becsülhető, és így nagyjából megháromszorozódik (de olykor ennél jobban növekszik) a helyes tizedesjegyek száma mindhárom közelítő szögharmadolási eljárásnál, azok egyszeri alkalmazásával. Az 1. és 3. eljárások esetén alsó becslés adódik, így akkor $\beta=\beta_{1}+\beta_{2}+\cdots+\beta_{n}$, a 2. eljárás esetén felső becslés adódik, akkor 
pedig $\beta=\beta_{1}-\beta_{2}+\beta_{3}-\cdots+(-1)^{n-1} \beta_{n}$ a szögharmadolás közelítése, ha $n$-szer alkalmazzuk ugyanazt a közelítő szögharmadolási eljárást egymás után a korábban leírt módon ( $n$ egy tetszőleges pozitív egész szám).

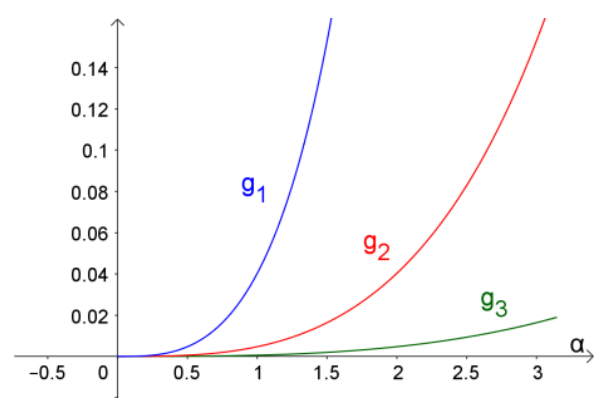

5. ábra. A $g_{i}(\alpha)=\left|\alpha-3 f_{i}(\alpha)\right|$ eltérésfüggvények $(\mathrm{i}=1,2,3)$

Mivel $\cos (\alpha / 3)$ a gyöke a $4 x^{3}-3 x=\cos (\alpha)$ egyenletnek, $\sin (\alpha / 3)$ pedig a gyöke a $3 x-4 x^{3}=\sin (\alpha)$ egyenletnek, ezért a numerikus módszerek standard gyökközelítési eljárásai is alkalmazhatók közelítő szögharmadolásra, hiszen egységszakaszt felvéve, egy adott $x$ hosszúságú szakasz esetén az $x^{2}, x^{3}, 1 / x$ hosszúságú szakaszok is mind megszerkeszthetők (pl. a párhuzamos szelők tételét alkalmazhatjuk e célból megfelelően sokszor), és így olyan szakasz is megszerkeszthető, amelynek hossza $x$-nek tetszőleges, racionális együtthatós racionális törtfüggvénye.

Ezért egyenlet átrendezéséből adódó iterációs módszerek (elsőrendü közelítés), a Newtonféle érintő módszer (másodrendủ közelítés), és a Newton-módszernél kevesebb számítást (és így jelen esetben kevesebb szerkesztési lépést) igénylő húrmódszer (elsőrendű közelítés) is megvalósíthatók szerkesztéssel, ld. [3]. Söt, simulókörrel történő gyökközelítés is szerkeszthetö (harmadrendü közelítés, ld. [10]), mivel $\sqrt{x}$ hosszúságú szakasz is szerkeszthető a Pitagorasztétel alkalmazásával; vagy a simulókört közelítő, az egyenlet polinomjának a görbéjén felvett 3 egymáshoz közeli ponton átmenö kört véve is kaphatunk gyökközelítést. Mindezekkel az eljárásokkal az a probléma, hogy sokkal hosszadalmasabban szerkeszthetők meg, mint az ebben a fejezetben korábban ismertetett három eljárás bármelyike, és nem adnak azoknál jobb közelítést.

Megemlítjük még, hogy Yates [11] könyvében jópár további, geometriai alapú közelítő szögharmadolási eljárást felsorol, de azok amikor jobb közelítést adnak, mint az ebben a fejezetben ismertetett 1-3. eljárások, akkor annyival több szerkesztési lépésből állnak azoknál, hogy sok tizedesjegynyi pontosságú közelítést kevesebb szerkesztési lépésből lehet megadni az 1-3. eljárásoknaka fejezetben korábban leírt módon történő egymás utáni alkalmazásával, mint a Yates által felsorolt módszerek többszöri alkalmazásával.

Jelölje $L(i, n)$ annak a szerkesztésnek a lépésszámát, amikor az $i$. eljárást $n$-szer egymás után alkalmazva egy szög közelítő harmadolását kapjuk, $P(i, n)$ pedig jelölje azt, hogy mennyi tizedesjegynyire pontosan jön ki ekkor a legfeljebb $60^{\circ}$-os szög harmadolása. (Mivel az eltérésfüggvények növekedők - ld. 5. ábra -, így elég a pontosan $60^{\circ}$ esetét vizsgálni.) $L(1, n)=11 n-7$, ha $n \geq 2$, ekkor mind a nyolc szerkesztési alaplépést használhatjuk. $L^{*}(1, n)=13 n-7$, ha csak az első hat szerkesztési lépést fogadjuk el alaplépéseknek, valamint a távolság körzőnyílásba vételét és az azzal a körzőnyílással való kör rajzolását egy lépésnek vesszük (ha ez utóbbit két lépésnek vesszük, akkor $L^{+}(1, n)=17 n-10$ a lépésszám).

Úgy kapjuk meg $L(1, n)$ értékét ( $n \geq 2$ esetén), hogy adott $A, B, C$ pontok és $c$ kör, valamint $A B$ és $A C$ szögszárak (egyenesek) esetén 3 lépésben lehet a $D$ és $E$ pontokat megszerkeszteni, 3 további lépés szükséges az $F$ pont megszerkesztéséhez, és utána 6 lépés 
szükséges $\alpha_{1}=\alpha-3 \beta_{1}$ megszerkesztéséhez úgy, hogy a c körön megszerkesztésre kerüljön egy olyan $G$ pont, amelyre $|B A G \angle|=\alpha_{1}$. Az utóbbi 9 lépés az 1. eljárás minden egyes újabb alkalmazásakor megtörténik, kivéve a végén, amikor $\alpha_{n}=\alpha_{n-1}-3 \beta_{n}$ megszerkesztésére nincs szükség, így akkor az utolsó 6 lépésre nincs szükség. Végül 2( $n-2)$ lépés szükséges $\beta_{1}+\beta_{2}+\cdots+\beta_{n}$ megszerkesztéséhez, mert a $\beta_{1}, \beta_{2}$ szögeket már az eljárás első két alkalmazásakor úgy szerkeszthetjük, hogy az $A B$ egyenes két különbözö félsíkjában legyenek, a többi $n-2$ esetben pedig egymás után felmérjük a szögeket a $c$ körön felvett pontok segítségével. Kiszámítható, hogy $P(1,1)=1, P(1,2)=5, P(1,3)=15$ adódik a tizedesjegyek pontosságára. Így az 1. eljárás háromszori alkalmazása során elérjük a 15 tizedesjegy pontos-ságot, a szerkesztési lépések száma ekkor $L(1,3)=26$ (ill. $L^{*}(1,3)=32$, és $\left.L^{+}(1,3)=41\right)$.

Továbbá kiszámítható, hogy $P(2,1)=2, P(2,2)=9, P(2,3) \geq 27, L(2, n)=17 n-5$; és $P(3,1)=3, P(3,2)=12, P(3,3) \geq 36, L(3, n)=19 n-5$, és így a 15 tizedesjegynyi pontosságot az 1. eljárás során érjük el a legkevesebb szerkesztési lépésben.

Az 1-3. eljárások többszöri alkalmazásáról nem mellékelünk ábrát, mivel egyre csökken a harmadolandó szögek nagyságrendje, és így mindegyik újbóli alkalmazás ábrázolása esetén másik, nagyobb léptékủ ábrára lenne szükség, ahol éppen csak az eljárás aktuális alkalmazása látszik, amely minden esetben ugyanúgy történik.

Az IEEE 754-es szabvány dupla pontosságúnál nagyobb pontosságú bináris lebegőpontos számformátumai a kiterjesztett ( 80 bites), a négyszeres (128 bites) és a nyolcszoros pontosságú (256 bites) számformátumok, melyek 18, 34, ill. 71 tizedesjegynyi pontosságot (azaz 63, 112, ill. 236 bináris jegynyi pontosságot) tesznek lehetővé. Mivel az 1-3. eljárások egyszeri újbóli alkalmazásával a szögharmadolás legalább háromszor annyi tizedesjegyre lesz helyes, így $P(1,4) \geq 45, P(1,5) \geq 135$, így az 1 . eljárást 4-szer alkalmazva, összesen $L(1,4)=37$ szerkesztési lépés során elérjük a 18, sőt a 34 tizedesjegynyi pontosságot is, valamint 5-ször alkalmazva, összesen $L(1,5)=48$ szerkesztési lépés során elérjük a 71 tizedesjegynyi pontosságot (az 1. eljárást érdemes választani, a három eljárás közül ennél lesz a legkisebb a lépésszám, amikor a becsült pontosságok elérik a kívánt számú tizedesjegynyit).

\section{Szoftveres korlátok, GeoGebrával történő ábrázolhatóság}

Mivel a GeoGebra numerikus számításokat végez el a pontok, egyenesek és körök ábrázolásához, ezért a túl nagy és túl kis léptékü ilyen típusú objektumokat nem lehet megjeleníteni. Úgy tünik, hogy csak $10^{-7}$ és $10^{154}$ közötti nagyságrendü paraméterek (koordináták, sugarak) esetén tudja ezeket ábrázolni a GeoGebra. Van, hogy az egyeneseket, köröket ábrázolja a GeoGebra, de a metszéspontjaikat nem, vagy nem jól ábrázolja (pl. körök metszéspontjait csak $10^{-5}$ nagyságrendű sugártól, kör és egyenes, valamint két egyenes metszéspontjait csak $10^{-7}$ nagyságrendủ paraméter értékektől). Emögött az lehet, hogy túl kis számokkal kellene dolgoznia a szoftvernek a metszéspontok kiszámításához.

Ezért a szerkesztések során érdemes a nagyon kis köröket elkerülni, helyettük másik, nagyobb köröket alkalmazni a szerkesztési lépések során. Szerencsére ez általában megvalósítható, esetleg néhány szerkesztési lépéssel hosszabb lesz emiatt a szerkesztés.

A GeoGebra fokban megadott szögek esetén teljes pontosságot jelez már 15-nél kevesebb számjegynyi egyezés esetén is: például a 3. eljárást kétszer alkalmazva, 12 tizedesjegynyi a pontosság radiánban számolva, de fokban mért szögnél mégis teljes pontosságot ( $0^{\circ}$ fok eltérést) jelez. Ennek oka, hogy a GeoGebra a szögeket fok formátumban történő tároláskor $180^{\circ}$ foknak a racionális törtjeiként tartja nyilván, amelynek során a 15 tizedesjegynyi pontosság helyett csak kevesebbel dolgozik. 
A geometriai szerkesztések szebbé, átláthatóbbá tehetők, ha bizonyos esetekben egész egyenesek helyett csak szakaszokat, és egész körök helyett csak köríveket ábrázolunk. Van, amikor érdemes körök sugarát is berajzolni megfelelő helyre, ha az ábrázolás egyértelmüségéhez ez szükséges.

Lehetőség szerint érdemes elkerülni egymáshoz nagyon közeli pontok, ill. nagyon rövid szakaszok szerkesztését, mert egy ábrában egyszerre nem szemléltethetők nagy és sok nagyságrenddel kisebb távolságok egyaránt. Ha mégsem lehet elkerülni ezt, akkor érdemes több ábrát készíteni a szerkesztésröl, vagy annak bizonyos részleteiről, különböző léptékekben, hogy a kis részletek is jól látszódjanak.

\section{5. Összefoglaló}

Meglepően kevés szerkesztési lépés elégséges szögharmadolás 15 tizedesjegynyi pontosságú szerkesztéséhez: 26 lépés (ill. 32 vagy 41 lépés, ha derékszögű vonalzó használatát nem engedélyezzük, és távolság körzőnyílásba történő felvételét és azzal a körzőnyílással történő, már megszerkesztett középpontú kör rajzolását 1 vagy 2 szerkesztési lépésnek vesszük), és mivel a szerkesztés pontosságának megháromszorozása aránylag kevés - tizenegy - szerkesztési lépéssel lehetséges, így 34, ill. 71 tizedesjegynyi pontosságú szögharmadolás is megvalósítható viszonylag kevés (37, ill. 48) szerkesztési lépéssel. De hiába lehetséges a geometriai mennyiségeknek (pontok koordinátáinak, távolságoknak, szögeknek, körsugaraknak) valamilyenpontosságú szoftveres megjelenítése, elöfordulhat, hogy a szerkesztésekben előforduló geometriai mennyiségek pontossága kicsit kisebb nagyságrendủ a szoftveres lebegőpontosszámformátum pontosságánál, a közbeeső számítások esetlegesen eltérő nagyságrendjei és ebből adódó számítási hibalehetőségek miatt. A szoftverrel elvégzett szerkesztések megjeleníthetöségéhez pedig szükséges a nagyon kis sugarú körök szerkesztésének elkerülése, amely megoldható esetenkénti néhánnyal több szerkesztési lépésben.

\section{Köszönetnyilvánítás.}

Szeretném megköszönni Németh Lászlónak, hogy erről a témakörről előadhattam Sopronban a Matematika Oktatása és Kutatása Szeminárium (MOKUS) 2019-es programjában.

\section{Irodalomjegyzék}

[1] Angle Trisection, Wikipedia, https://en.wikipedia.org/wiki/Angle_trisection

[2] Angle Trisection, Wolfram MathWorld, https://mathworld.wolfram.com/AngleTrisection.html

[3] Faragó, I., Horváth R., Numerikus módszerek, BME Matematika Intézet, Budapest (2011), pp. 309.

[4] Fritz, J., Kónya, I., Függvénysorok, BME Villamosmérnöki és Informatikai Kar, Budapest (2007), pp. 51.

[5] Gauld, D., Approximate Angle Trisection, The College Mathematics Journal 15 No. 5 (1984), pp. 420-422.

[6] GeoGebra, https://www.geogebra.org/

[7] IEEE lebegőpontos számformátum, Wikipédia, https://hu.wikipedia.org/wiki/IEEE_lebeg\%C5\%91pontos_sz\%C3\%A1mform\%C3\%A1tum

[8] IEEE 754, Wikipédia, https://en.wikipedia.org/wiki/IEEE_754

[9] Kovács, Z., Geometria szerkesztések I. (Euklidészi szerkesztések), Debreceni Egyetem Matematikai és Informatikai Intézete, Debrecen (2001), pp. 23., http://zeus.nyf.hu/ kovacsz/szerk.pdf

[10]Osculating circle, Wikipedia, https://en.wikipedia.org/wiki/Osculating_circle

[11] Yates, R., The Trisection Problem, National Council of Teachers of Mathematics, Washington D.C. (1971), pp. 78. 